\title{
Carbide Formation from a Montmorillonite-Polyacrylonitrile Intercalation Compound by Carbothermal Reduction
}

\author{
Yoshiyuki SUGAHARA, Kenichi SUGIMOTO, Kazuyuki KURODA \\ and Chuzo KATO \\ (Department of Applied Chemistry, School of Science and Engineering, Waseda University) \\ 3-4-1, Ohkubo, Shinjuku-ku, Tokyo 160
}

\begin{abstract}
The montmorillonite-polyacrylonitrile (PAN) intercalation compound was heated in $\mathrm{Ar}$ flow for the application of clay-organic complexes to the preparation of carbide through the carbothermal reduction. $\beta$-SiC was formed at $1200^{\circ} \mathrm{C}$ and both $\alpha$ - SiC and $\beta$-SiC were detected above $1300^{\circ} \mathrm{C}$. $\mathrm{SiO}_{2}$ component was reduced without forming any crystalline compounds, while $\mathrm{Al}_{2} \mathrm{O}_{3}$ component formed $\mathrm{Mg}-\mathrm{Al}-\mathrm{O}$ compound. Compared with the reactions of a montmorillonite-carbon mixture, it was clarified that the presence of PAN in the interlayer space led to the formation of $\alpha$-SiC and suppressed the crystallization of oxides.

[Received July 24, 1985]
\end{abstract}

\section{モンモリロナイトーポリアクリロニトリル層間化合物からの 熱炭素還元による炭化物生成}

菅原義之・杉本健一・黒田一幸・加藤忠蔵

(早稲田大学 理工学部 応用化学科)

\begin{abstract}
粘土一有機複合物を熱炭素還元による炭化物合成に応用することを目的として，モンモリロナイ

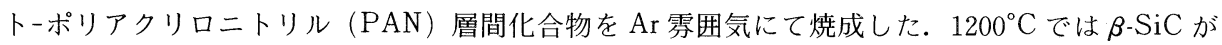
生成し, $1300^{\circ} \mathrm{C}$ 以上では $\alpha$-及び $\beta-\mathrm{SiC}$ が生成した。酸化物では $\mathrm{SiO}_{2}$ 成分が全く結晶化しなかっ たのに対し, $\mathrm{Al}_{2} \mathrm{O}_{3}$ 成分は $\mathrm{Mg}-\mathrm{Al}-\mathrm{O}$ 系の化合物として結晶化した。モンモリロナイト-炭素混合 物からの反応との比較により, 層間の PAN の存在が $\alpha-\mathrm{SiC}$ の生成をもたらし, 酸化物の結晶化を 抑制したことが明らかとなった。

(1985 年 7 月 24 日受付)
\end{abstract}

Key-words : Intercalation compound, Montmorillonite, Polyacrylonitrile, Silicon carbide, Carbothermal reduction

\section{Introduction}

Silicon carbide is expected as a candidate for structural materials. Among the preparation methods, the carbothermal reduction of $\mathrm{SiO}_{2}$ is one of the main procedures, and is utilized for the industrial fabrication as "Acheson process" ${ }^{1}$. In spite of its industrial importance, the process has not been investigated sufficiently. Recently, the syntheses from various $\mathrm{SiO}_{2}$ sources have been studied. Wei et al. ${ }^{2)}$ prepared $\mathrm{SiC}$ powder from gel-derived precursors, which gave more intimate mixture of $\mathrm{SiO}_{2}$ and carbon. Lee et al. ${ }^{3)}$ first reported the formation of $\mathrm{SiC}$ from rice hull by thermal decomposition and subsequent reduction. Sharma et al. ${ }^{4)}$ also reported the formation of $\mathrm{SiC}$ whisker from it. Moreover, the synthesis from $\mathrm{SiO}_{2}-\mathrm{Al}_{2} \mathrm{O}_{3}$ compositions was investigated, since a large part of compounds containing $\mathrm{SiO}_{2}$ exists as aluminosilicates. The first preparation was reported by Bechtold et al. ${ }^{5}$. They used a typical clay mineral of kaolinite, and obtained $\mathrm{SiC}$ with the successful separation of $\mathrm{Al}_{2} \mathrm{O}_{3}$. The synthesis from Shirasu glass was also studied. Shimada et al. ${ }^{6)}$ reported the formation of $\mathrm{SiC}$ with the formation of Al-rich glass. They also studied the result of sintering ${ }^{7)}$. 
Montmorillonite, which is one of common clay minerals, has a specific property of "intercalation", and can form intercalation compounds with a wide variety of organic molecules ${ }^{8)}$. Among complexes, the montmorillonite-polyacrylonitrile (PAN) intercalation compound was used as a starting material for the synthesis of nitrides through carbothermal reduction ${ }^{9}$. In the complex, the layers of montmorillonite and PAN, whose thickness is about $1 \mathrm{~nm}$, are stratified alternatively. Thus the intimate mixture of oxide and carbon could be obtained by their thermal transformation in an inert atmosphere. In this study, the behavior on the carbide formation from the montmorillonite-PAN complex was investigated, comparing with that of a montmorillonite-carbon mixture. This investigation could clarify the advantage arisen from the formation of the intercalation compounds, and the possibility of being a starting material for the synthesis of $\mathrm{SiC}$.

\section{1 Sample preparation}

The preparation of the $n$-hexylammoniummontmorillonite-PAN intercalation compound and its heat treatment for cyclization of PAN were described elsewhere ${ }^{9}$. It is assumed that a certain amount of PAN was adsorbed on the external surface of the particles as well as in the interlayer spaces. Nevertheless, it is reasonable to consider that the presence of the carbon on the external surface scarcely influenced to the whole reaction process in an inert atmosphere due to the reactions previously reported ${ }^{3)}$. Thus its effect could be excluded. In this study, the amount of organic materials determined by TG was about $61 \mathrm{wt} \%$ after the heat treatment. According to the report on the synthesis of carbon fiber ${ }^{10)}, 42-56$ wt $\%$ of PAN was transformed to carbon. Thus, the actual amount of carbon which was involved in the reactions was considered to be about a half of that of organic materials contained in the sample before firing in Ar.

The preparation of the montmorillonite-carbon mixture was as follows. Montmorillonite $(-100$ mesh) and carbon black (Koso Chemical Co., reagent grade) were mixed using $n$-hexane. The mixing rate of carbon was $26.9 \mathrm{wt} \%$, which was stoichiometric for the formation of $\mathrm{SiC}$ from $\mathrm{SiO}_{2}$ component.

\section{2 Heat treatment in $\mathrm{Ar}$}

About $0.7 \mathrm{~g}$ of sample $(-100 \mathrm{mesh})$ was heated in Ar flow for $1 \mathrm{~h}$. Reaction temperature varied from $1100^{\circ} \mathrm{C}$ to $1400^{\circ} \mathrm{C}$. After decarbonization at $650^{\circ} \mathrm{C}$ for $3 \mathrm{~h}$, products were analyzed by X-ray Diffraction (XRD) (Rigaku Denki, RAD II-A, Fe $K \alpha$ ) to identify crystalline phases. IR spectra were measured using Hitachi Infrared Spectrophotometer 260-50. The sample was mixed with dried $\operatorname{KBr}(1: 50)$ and pressed into a pellet, and its spectrum was recorded in the region from 1500 to $250 \mathrm{~cm}^{-1}$. The morphology of the products was studied by Hitachi HXM-2B, and its electron probe microanalysis was also conducted using the same instrument.

\section{Results and discussion}

\subsection{Thermal transformation of montmorillon-} ite

At beginning, the thermal transformation of montmorillonite under the same condition was investigated to identify the oxides formed at high temperatures. Results are summarized in Table 1.

Table 1. High temperature crystalline phases of montmorillonite*.

\begin{tabular}{lcc}
\hline $\begin{array}{c}\text { Reaction } \\
\text { Temperature } \\
\left({ }^{\circ} \mathrm{C}\right)\end{array}$ & $\begin{array}{l}\text { Heating } \\
\text { Time }\end{array}$ & \\
\hline 1100 & 1 & Cristobalite, Mullite, Spinel \\
1200 & 1 & Mullite $>$ Cordierite, Spinel \\
1300 & 1 & Mullite $>$ Cordierite \\
1400 & 1 & Mulite > Cordierite \\
\hline * Samples were heated in Ar flow.
\end{tabular}

Table 2. Heating condition and crystalline composition.

\begin{tabular}{|c|c|c|c|}
\hline \multirow{3}{*}{$\begin{array}{l}\text { Reaction } \\
\text { temp. } \\
\qquad\left({ }^{\circ} \mathrm{C}\right)\end{array}$} & \multirow{3}{*}{$\begin{array}{l}\text { Heating } \\
\text { time } \\
\text { (h) }\end{array}$} & \multicolumn{2}{|c|}{ Phases } \\
\hline & & complex & mixture \\
\hline & & & \\
\hline 1100 & 1 & & spinel, Mullite \\
\hline 1200 & 1 & $\beta^{-S i C}$ & $\beta$-SiC, spinel, Mullite, Cordierite \\
\hline 1300 & 1 & $\beta^{-S i C,} \alpha-S i C, M g-A l-0^{\star \star}$ & $\beta_{\text {-SiC, spinel, Mullite, Cordierite }}$ \\
\hline 1400 & 1 & $\beta$-SiC, $\alpha$-SiC, Mg-Al-O & $\beta_{\text {-SiC, spinel, Mullite, Cordierite }}$ \\
\hline
\end{tabular}

** Al rich composition with spinel structure 
Table 1 shows the formation of cristobalite, mullite, cordierite as $\mathrm{SiO}_{2}$ related oxides, and spinel as a $\mathrm{SiO}_{2}$-free oxide. The results agreed with the previous report ${ }^{11 !}$.

\subsection{Variation of crystalline phases with reac- tion temperature}

Table 2 lists the crystalline phases obtained from both the montmorillonite-PAN complex and the montmorillonite-carbon mixture. Figure 1 shows the XRD patterns of products from the montmorillonite-PAN complex, and Fig. 2 reveals the XRD patterns from the montmorillonitecarbon mixture.

In the reactions of the montmorillonite-PAN complex, the pattern at $1100^{\circ} \mathrm{C}$ revealed no crystalline phases, indicative the presence of oxides as an amorphous form. At $1200^{\circ} \mathrm{C}$, the formation of $\beta$ - $\mathrm{SiC}$ was observed, while both $\alpha$ and $\beta$-SiC were formed above $1300^{\circ} \mathrm{C}$. The behavior on the formation of oxides was quite different from that of montmorillonite (Table 2). The only formation of oxide as an $\mathrm{Al}-\mathrm{Mg}-\mathrm{O}$

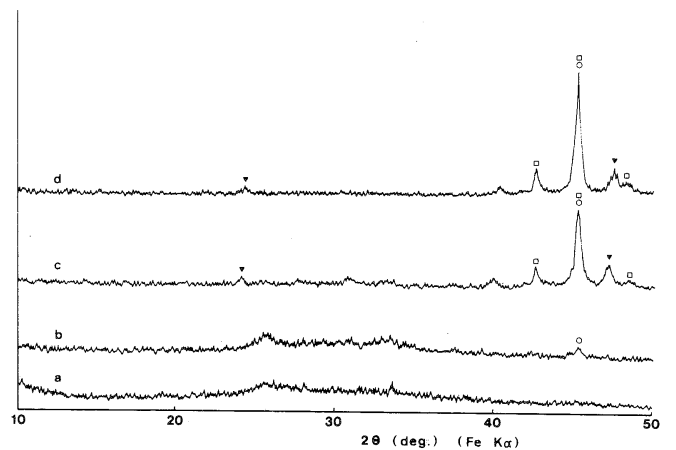

Fig. 1. XRD patterns of products from montmorillonite-PAN complex;

(a) $1100^{\circ} \mathrm{C}$, (b) $1200^{\circ} \mathrm{C}$, (c) $1300^{\circ} \mathrm{C}$, (d) $1400^{\circ} \mathrm{C}$ $(\square: \alpha-\mathrm{SiC}, \bigcirc: \beta-\mathrm{SiC}, \boldsymbol{\nabla}: \mathrm{Mg}-\mathrm{Al}-\mathrm{O})$.

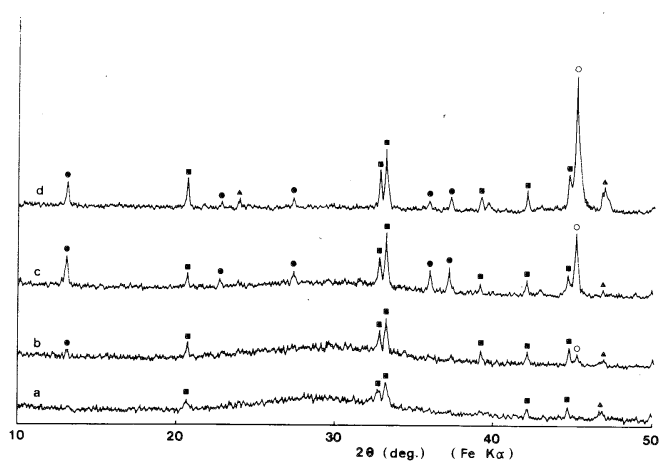

Fig. 2. XRD patterns of products from montmorillonite-carbon mixture :

(a) $1100^{\circ} \mathrm{C}$, (b) $1200^{\circ} \mathrm{C}$, (c) $1300^{\circ} \mathrm{C}$, (d) $1400^{\circ} \mathrm{C}$

$(\bigcirc: \beta$-SiC, $\mathbf{\square}:$ Mullite, $:$ Cordierite, $\boldsymbol{\Delta}:$ Spinel). compound with spinel structure ${ }^{12)}$ was observed above $1300^{\circ} \mathrm{C}$. The compound contained much more $\mathrm{Al}_{2} \mathrm{O}_{3}$ than spinel, and the formation of the compound instead of spinel was indicated by the shift of each peak to higher angle than that of spinel. And no oxides containing $\mathrm{SiO}_{2}$ were detected.

In Fig. 2, on the other hand, the formation of oxides was almost the same as Table 1 except the formation of no crystalline $\mathrm{SiO}_{2}$. Mullite was formed above $1100^{\circ} \mathrm{C}$, and cordierite was detected above $1200^{\circ} \mathrm{C}$. Furthermore, spinel formed above $1100^{\circ} \mathrm{C}$ with the same composition as that formed by the thermal transformation of montmorillonite. $\mathrm{SiC}$ was formed above $1200^{\circ} \mathrm{C}$ only in the $\beta$ modification, and the corresponding intensity decrease of peaks due to cordierite was observed at $1400^{\circ} \mathrm{C}$.

The most notable fact indicated from Fig. 1 and Fig. 2 was that the formation of $\alpha$-SiC was observed only in the reactions of the montmorillonite-PAN complex. This suggests that the reaction process of the montmorillonite-PAN complex differs from that of the montmorillonitecarbon mixture. However, the mechanisms of the formation of $\alpha$ - and $\beta$-SiC through carbothermal reduction have not been clarified yet, thus this difference could not be interpreted.

In the investigation of the preparation from Shirasu glass, Shimada et al. ${ }^{6)}$ reported $2 \mathrm{H}$ type of $\alpha$ - $\mathrm{SiC}$ above $1600^{\circ} \mathrm{C}$ in Ar flow. And Hase et al. ${ }^{13)}$ reported the formation of $2 \mathrm{H}$ from colloidal silica and carbon in the presence of $\mathrm{Al}$ at $1440^{\circ} \mathrm{C}$ in ca. $10^{-1} \mathrm{mmHg}$. These results suggest that the presence of $\mathrm{Al}$ leads to the formation of $2 \mathrm{H}$ among $\alpha$-SiC polytypes at relatively lower temperatures through carbothermal reduction process.

However, the XRD patterns revealed the possibility of the formation of both $2 \mathrm{H}$ and $4 \mathrm{H}$, because of the lacking of the characteristic peaks of $2 \mathrm{H}$ and $4 \mathrm{H}$ and the overlapping of the peaks with those of $\beta$-SiC. Although the thermal stability also indicated that the formation of $2 \mathrm{H}$ was more probable than that of $4 \mathrm{H}^{14), 15)}$, the possibility of the formation of $4 \mathrm{H}$ could not be excluded due to the stabilization of $4 \mathrm{H}$ by $\mathrm{Al}$ at higher temperatures ${ }^{16,177}$.

The behavior of the formation of oxides was also quite different between two processes. The suppression of the formation of oxides was arisen from the presence of PAN in the interlayer spaces; PAN divided the particle into each sili- 
cate layer, thus the crystallization was inhibited, and the amorphous state was stabilized. The same observation was reported by Oya et $a^{18)}$.

While no oxides concerning $\mathrm{SiO}_{2}$ were observed, $\mathrm{Al}_{2} \mathrm{O}_{3}$ component crystallized as the $\mathrm{Mg}-\mathrm{Al}-\mathrm{O}$ compound in the case of the montmorillonite-PAN complex. This finding was explained with the difference of reactivity over carbon between $\mathrm{SiO}_{2}$ and $\mathrm{Al}_{2} \mathrm{O}_{3}{ }^{19}$. The comparison with the reactions of the montmorillonitecarbon mixture indicates that the presence of PAN also influence the composition of the oxide formed.

\subsection{IR spectra of products}

Figure 3 shows the IR spectra of the products from the montmorillonite-PAN complex, and IR spectra from the montmorillonite-carbon mixture are shown in Fig. 4.

In the case of the montmorillonite-PAN complex, a band due to the Si-O stretching was clearly observed from $1100^{\circ} \mathrm{C}$ to $1300^{\circ} \mathrm{C}$, indica-

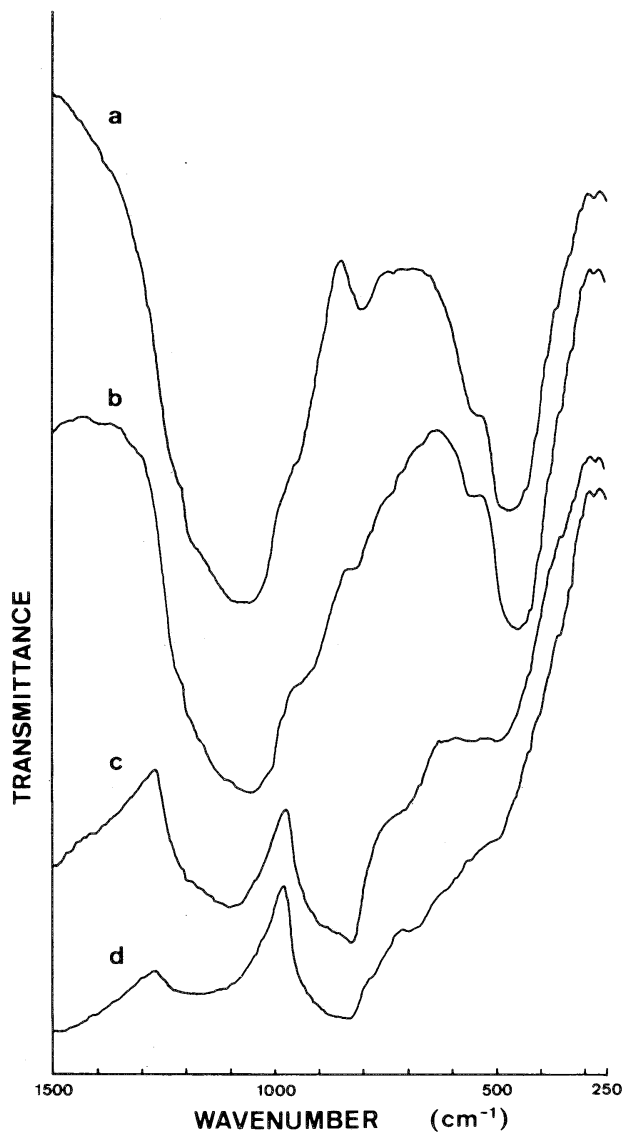

Fig. 3. IR spectra of products from montmorillonite-PAN complex;
(a) $1100^{\circ} \mathrm{C}$, (b) $1200^{\circ} \mathrm{C}$, (c) $1300^{\circ} \mathrm{C}$, (d) $1400^{\circ} \mathrm{C}$.

tive the presence of amorphous $\mathrm{SiO}_{2}$ component. Above $1300^{\circ} \mathrm{C}$, a strong absorption band at ca. $820 \mathrm{~cm}^{-1}$ was observed. In the previous reports, the spectra of $\beta$-SiC showed the band at $820-870 \mathrm{~cm}^{-120)}$, and the band at $820-830 \mathrm{~cm}^{-1}$ was observed with the shoulder bands at $790 \mathrm{~cm}^{-1}$ and $940 \mathrm{~cm}^{-121)}$ in the case of $\alpha-\mathrm{SiC}(6 \mathrm{H})$. Thus the band observed was assigned to $\alpha$ - and $\beta$-SiC.

On the other hand, the well-defined band at $\mathrm{ca}$ $820 \mathrm{~cm}^{-1}$ appeared only at $1400^{\circ} \mathrm{C}$ in Fig. 4. This finding implied the advantage of the montmorillonite-PAN complex over the montmorillonitecarbon mixture, though no considerable difference was observed in their XRD peaks due to $\mathrm{SiC}$ at $1300^{\circ} \mathrm{C}$ (Figs. 1 and 2).

\section{4 SEM observation and electron probe microanalysis}

The SEM observation of the products from the montmorillonite-PAN complex (Figs. $5 \mathrm{a}$ and b) showed the characteristic shape similar to the original montmorillonite particles. In addition, fine products were also observed on their surfaces, especially the edge or defect of the particle. Using electron probe microanalysis, the product was assumed to be $\mathrm{SiC}$. This assignment was based on the fact that a lesser amount of Al was detected in this area than in other area. It is well

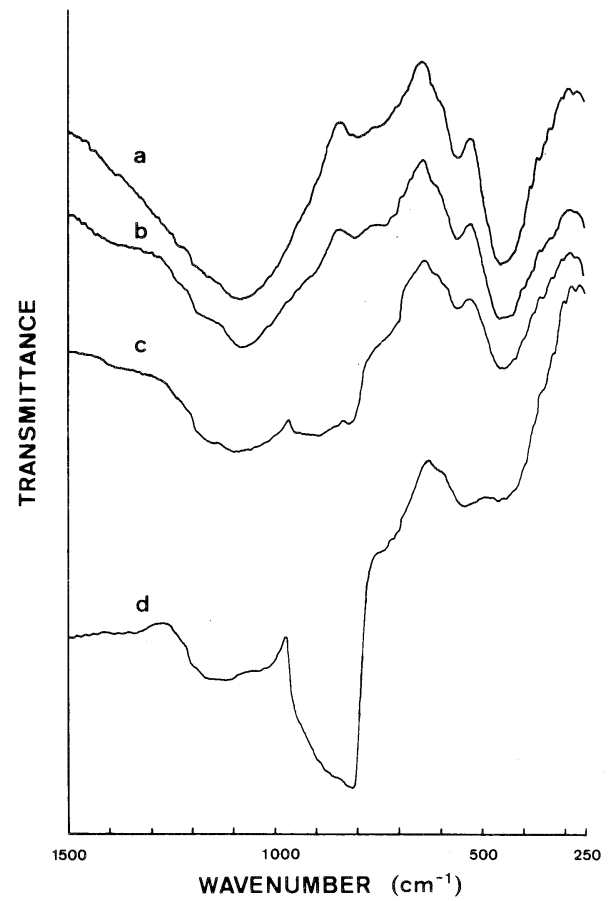

Fig. 4. IR spectra of products from montmorillonitecarbon mixture;

(a) $1100^{\circ} \mathrm{C}$, (b) $1200^{\circ} \mathrm{C}$, (c) $1300^{\circ} \mathrm{C}$, (d) $1400^{\circ} \mathrm{C}$. 

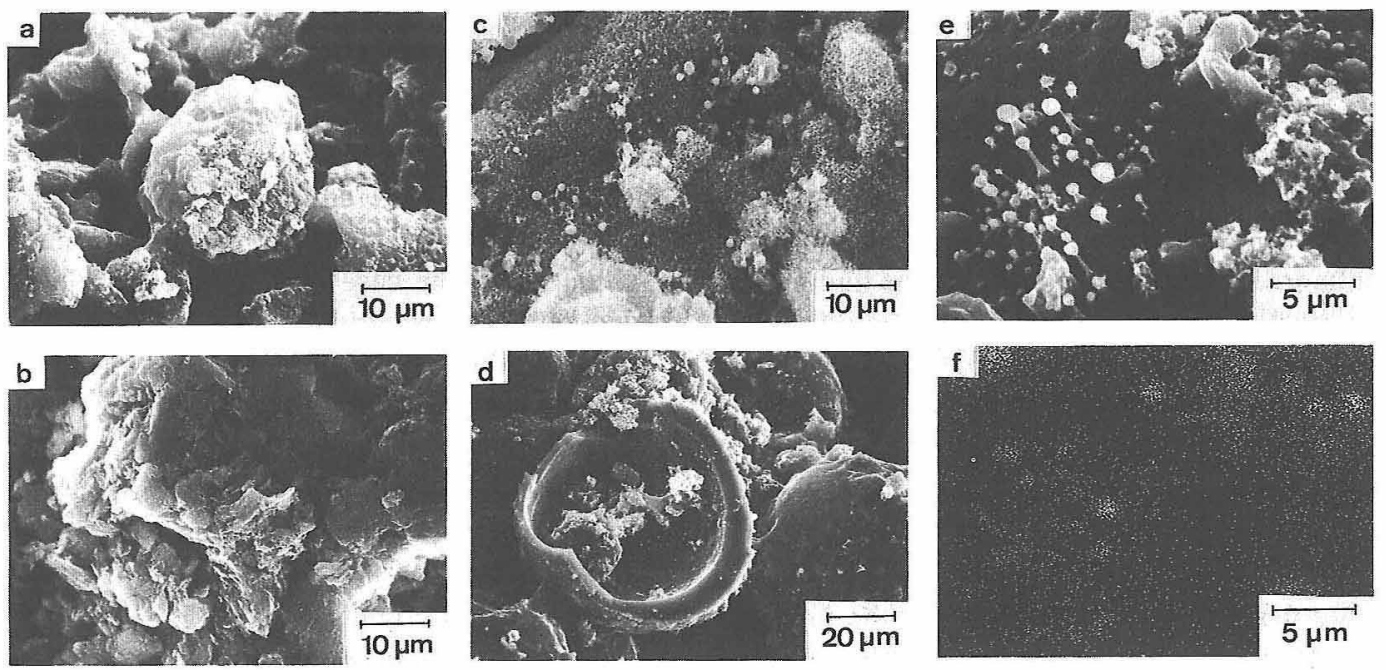

Fig.5. Scanning electron micrographs of products

(a), (b) from montmorillonite-PAN complex;

(a) $1400^{\circ} \mathrm{C}$, (b) $1300^{\circ} \mathrm{C}$

(c)-(e) from montmorillonite-carbon mixture;

(c) $1400^{\circ} \mathrm{C}$, (d) $-\left(\right.$ e) $1300^{\circ} \mathrm{C}$

(f) X-ray image of (e); $\mathrm{Fe} K \alpha$.

known that the formation of $\mathrm{SiC}$ proceeded via the formation of $\mathrm{SiO}$ as an intermediate ${ }^{31}$. Thus this was explained on the the assumption that $\mathrm{SiO}$ formed in the interior of the particles reacted on the surface to form the fine $\mathrm{SiC}$.

On the contrary, the surface of the montmorillonite-carbon mixture (Figs. 5 c-e) was quite different from that of the montmorillonite-PAN complex. At $1400^{\circ} \mathrm{C}$, the particles were not spherical, whereas most of the particles obtained at $1300^{\circ} \mathrm{C}$ showed spherical shapes. In addition, the hollow particles was also detected at $1300^{\circ} \mathrm{C}$ (Fig. $5 \mathrm{~d}$ ). The surface of the product at $1400^{\circ} \mathrm{C}$ was covered by fibrous products completely. And on the top of the products, spherical products were occasionally observed. The micrograph of the products at $1300^{\circ} \mathrm{C}$ (Fig. 5 e) revealed that the fibrous products grew from the surface of the spherical particle. Electron probe microanalysis of the surface of the spherical particle suggests the fact that fine products are $\mathrm{SiC}$ and spherical products contain a certain amount of $\mathrm{Fe}$ (Figs. $5 \mathrm{e}$ and $\mathrm{f}$ ). During the carbothermal reduction of a $\mathrm{SiO}_{2}-\mathrm{Fe}_{2} \mathrm{O}_{3}$ mixture, the formation of $\mathrm{FeSi}$ was reported ${ }^{22}$. Thus, this observation was probably due to the progress of such reaction on the surface, although no evidence was obtained from their XRD patterns. These observation indicated that the surface reactions were completely different. However, the reason of the difference has not be clarified.

\section{Conclusion}

The montmorillonite-PAN intercalation compound was heated in $\mathrm{Ar}$ flow from $1100^{\circ} \mathrm{C}$ to $1400^{\circ} \mathrm{C}$, and its behavior was compared with that of the montmorillonite-carbon mixture.

From the montmorillonite-PAN complex, both $\alpha$ - and $\beta$-SiC were formed, while only the formation of $\beta$ - $\mathrm{SiC}$ was observed in the case of the montmorillonite-carbon mixture. And mullite and cordierite were not detected in the reactions of the montmorillonite-PAN complex, though these oxides crystallized in the case of the montmorillonite-carbon mixture, In contrast, $\mathrm{Mg}-\mathrm{Al}-\mathrm{O}$ compounds crystallized in both reactions, but their compositions were different; the compound from the montmorillonite-PAN complex contained much more $\mathrm{Al}_{2} \mathrm{O}_{3}$ than that from the montmorillonite-carbon mixture.

Moreover, IR spectra implied that the montmorillonite-PAN complex was more reactive than that of the montmorillonite-carbon mixture. And the analyses by SEM and EPMA also indicated that the surface reaction was different.

These findings suggest that the reaction process becomes completely different. All of these results were due to the existence of PAN in the interlayer space. 
Acknowledgment The authors thank to Mr. S. Suzuki (The Castings Research Laboratory of Waseda University) for his help in analyses using SEM and EPMA.

\section{References}

1) W.F. Knippenberg, Philips Res. Repts., 18, 161-274 (1963).

2) G. C. Wei, C. R. Kennedy and L. A. Harris, Am. Ceram. Soc. Bull., 63, 1054-61 (1984).

3) J. G. Lee and I. B. Cutler, ibid., 54, 195-98 (1975).

4) N. K. Sharma, W. S. Williams and A. Zangvil, J. Am. Ceram. Soc, , 67, 715-20 (1984).

5) B. C. Bechtold and I. B. Cutler, J. Am. Ceram. Soc., 63, 271-75 (1980).

6) K. Shimada, Y. Fukushige, Y. Hirata and Y. Suekawa, Yogyo-Kyokai-Shi, 92, 118-25 (1984).

7) Y. Hirata, Y. Suekawa and K. Shimada, Yogyo-Kyokai Shi, 92, 126-34 (1984).

8) B. K. G. Theng, "The Chemistry of Clay-Organic Reactions", Adam Hilger, London (1974) p. 17.

9) Y. Sugahara, K. Kuroda, and C. Kato, J. Am. Ceram. Soc., 67, C 247-48 (1984).

10) K. Nukada and K. Kobori, Kobunshi, 23, 445-48 (1974).

11) H. Takeshi and Y. Uno, Miner. Soc. Japan Spec. Pap.,
1, 98-105 (1971).

12) Von. H. Saalfeld and H. Jagodzinski, Z. Kristallogr., 109, 87-109 (1957).

13) T. Hase, H. Suzuki and T. Iseki, Yogyo-Kyokai-Shi, 87, 576-82 (1979).

14) Y. Inomata, M. Mitomo, Z. Inoue and H. Tanaka, Yogyo-Kyokai-Shi, 77, 130-35 (1969).

15) T. Tagai, S. Sueno and R. Sadanaga, Kobutsu-GakkaiShi, 9, 475-78 (1970).

16) M. Mitomo, Y. Inomata and M. Kumanomido, YogyoKyokai-Shi, 78, 224-28 (1970).

17) G. A. Bootsma, W.F. Knippenberg and G. Verspui, J. Crystal Growth, 8, 341-53 (1971).

18) A. Oya, Y. Omata and S. Otani, J. Mater. Sci., 20, 255-60 (1980).

19) W. J. Kroll and A.W. Schlechen, Trans, Electrochem. Soc., 93, 247-58 (1948).

20) T. Hase and H. Suzuki, Yogyo-Kyokai-Shi, 86, 541-46 (1978).

21) A. Borghesi, E. Bussoletti, L. Colangeli and C. De. Blasi, Infrared Phys., 23, 321-28 (1983).

22) E. Schürmann, C. Zellerfeld and E. Bepper, Arch. Eisenhüttenwes. , 48, 217-22 (1977). 